\title{
Micro RNAs In Periodontal Disease - A Review
}

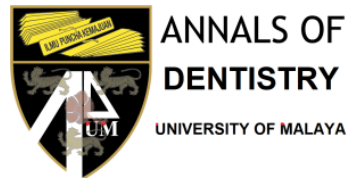

www.adum.edu.my

Ann Dent UM 2020, 27: 11-21 Dol: 10.22452/adum.vol27no3

\author{
Mekha Grace Varghese ${ }^{1 *}$, Thomas George Valliaveettil ${ }^{1}$, Annie \\ Kitty George ${ }^{1}$, Saranya Rajan ${ }^{1}$
}

\section{KEYWORDS}

microRNA; biogenesis; profiling; innate immunity; acquired immunity; bone remodelling

\begin{abstract}
microRNAs (miRNAs) constitute a family of small, non-coding RNA molecules that regulate gene expression and protein expression. microRNAs have influence on a broad range of physiologic and pathologic conditions. They are also considered as promising biomarkers especially when they are secreted extracellularly. In the inflammatory pathways, they dysregulate the molecular processes and contribute to the development of chronic inflammatory diseases including periodontitis. In this review, we provide an overview of miRNA characteristics, biogenesis, mechanisms of action and profiling methods. In addition, the role of miRNAs in the pathobiology of periodontitis, especially those pertaining to the cellular and molecular pathways of inflammation has been considered to enhance our understanding of the pathobiology of periodontitis.
\end{abstract}

\section{INTRODUCTION}

The central dogma of molecular biology, introduced by Crick in 1958, states that biological information is transferred from DNA to messenger RNA (mRNA) and to protein in a linear and sequential manner [1]. The microRNAs (miRNAs) take a prominent role in this context. They are the recently discovered family of small non-coding RNA molecules that is 22 nucleotides long. Their function is either to inhibit the initiation of mRNA translation into proteins or to induce degradation of mRNA molecules. Thus they have massive effects on protein translation. About $60 \%$ of all protein-coding genes are targets of miRNAs [2]. They have a major role in the normal development and are critical in many biological processes. They can be secreted into the extracellular fluids like plasma, serum, tears, colostrum, saliva etc. From there, they will be delivered to target tissues to act in an autocrine, paracrine or endocrine fashion thereby modulating the cellular activities. Thus miRNAs have a hormone

\footnotetext{
${ }^{* 1}$ Department of Periodontics, Pushpagiri College of Dental Sciences, Perumthuruthy, Thiruvalla, Kerala, India.

*Correspondence: mekhagrace@gmail.com
}

like behaviour too. This property enables its use as a biomarker for diagnostic applications in diseases like cancer, cardiovascular and autoimmune diseases.

The first described miRNA was lin-4 by Victor Ambros and Gary Ruvkun [3,4] based on work carried out in the Caenorhabditis elegans nematode. Since then, additional miRNAs have been discovered to a total of 2,588 mature miRNAs in humans and 1,915 miRNAs in mice [5]. Regulation of protein expression by miRNAs has an important role in homeostasis as well as pathology. Aberrant miRNA can dysregulate both the innate and adaptive immune responses. This dysregulation develops into chronic inflammatory diseases. This review aims to provide an overview of basic miRNA biology and its relation to inflammatory periodontal disease.

\section{MIRNA CHARACTERISTICS}

Mature miRNAs are typically 22 nucleotides long but their origin is from much longer primary transcripts. The biogenesis of mature miRNA starts 
from DNA sequences. RNA polymerase II enzyme transcribes the DNA sequences to primary transcript, known as the pri-miRNA. The primary transcripts are usually 100 to 1000 nucleotides long and has a characteristic stem loop structure. The cleavage of primary transcripts give rise to premiRNA/ precursor miRNA that are 70 to 100 nucleotide long and has a hairpin loop structure. Further cleavage of pre-miRNA by the RNA polymerase III enzyme results in a miRNA duplex strand with a $3^{\prime}$ and $5^{\prime}$ end. The duplex strand is composed of a guide strand and passenger strand. Guide strand is thermodynamically more stable and gets incorporated into the RNA-induced silencing complex (RISC) where they are bound by a member of the Argonaute (AGO) family of RNA-binding proteins. The passenger strand is thermodynamically less stable and are often degraded (Figure: 1).

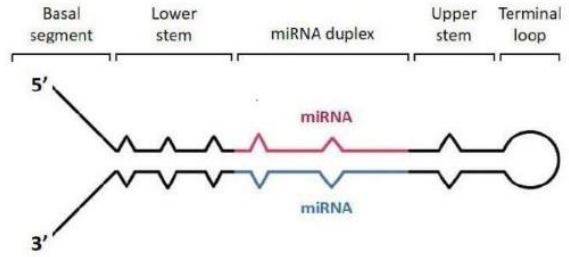

Figure 1: The typical stem-loop structure of miRNA. The typical stem loop structure of miRNA. It consists of a terminal loop about 10 nucleotide long, a miRNA duplex approximately 22 nucleotide long, a lower stem 11 nucleotide long and two flanking segments, 9 nucleotide long with a 3 ' and $5^{\prime}$ end. The miRNA duplex consists of a guide strand and passenger strand. The guide strand is the functional strand and the passenger strand is often degraded.

MicroRNA represents about $0.01 \%$ of total RNA by weight but the average copy number of an individual miRNA species has been estimated as $500 /$ cell. They represent only a tiny fraction of total RNA quantity yet they are numerous because of the much lower molecular weight compared to mRNA.

\section{BIOGENESIS OF MIRNA}

The generation of genome-encoded miRNA precursors occurs in the nucleus and their transportation and further processing takes place in the cytoplasm [6]. Genes encoding for miRNAs can be found between the protein-coding genes, as polycistronic transcripts under their own promoters, or in the intronic regions of proteincoding genes that often encode multiple endproduct miRNAs [7]. Transcription of miRNA genes is mainly by RNA polymerase II and RNA polymerase III [8]. The RNA polymerase II enzyme cleaves the DNA sequences. They produce long pri-miRNAs. The maturation process involves two consecutive cleavage steps by RNase III enzymes DROSHA and DICER. A heterotrimeric complex formed by DROSHA and its partner DiGeorge syndrome critical region gene 8 (DGCR8) [9] crops the pri-miRNA into pre-miRNAs [10]. Pre-miRNA is then exported to cytoplasm with the help of Exportin-5-Ran-GTP complex [11] where DICER cleaves it and forms a mature miRNA duplex. Dicer acts together with Argonaute-2(AGO2). Mature miRNA is approximately 22-nucleotide long and is composed of guide-strand and passenger strand duplexes and the process is referred to as 'dicing'. This is the classical (canonical) pathway of biogenesis (Figure: 2).

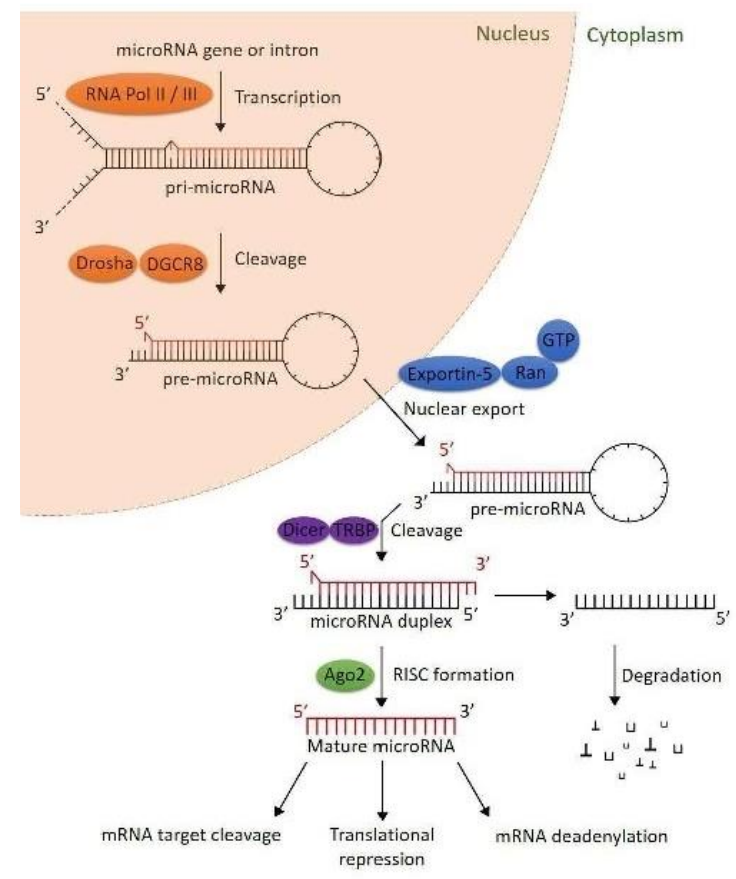

Figure 2: The canonical pathway of miRNA biogenesis. The canonical pathway of miRNA biogenesis. It involves the production of pri-miRNA by RNA polymerase II or III followed by cleavage of pri-miRNA by the microprocessor complex (DROSHA-DGCR8) in the nucleus. The resultant, premiRNA is exported from nucleus to cytoplasm by Exportin 5- RanGTP complex. In the cytoplasm it is again cleaved by DICER and TRBP, the double stranded RNA binding protein, to form mature miRNA duplex. The guide strand gets incorporated into the RISC along with Ago2 protein and takes part in mRNA cleavage, 
translational repression or deadenylation where as the passenger strand undergoes degradation.

Then there is the alternative processing pathways of pre-miRNA. It is independent of either Drosha or Dicer, i.e. formed either by Drosha independent pathway or by Dicer independent pathway. The imprecisions in Drosha and Dicer cleavage of miRNA precursors lead to formation of length variant or shifted sequenced [12] miRNAs called 'isomiRs' $[13,14]$. Most isomiRs vary by one or more bases at the $3^{\prime}$ and/or $5^{\prime}$ end, in size, from the canonical miRNA. The variations at the 5'end are functionally relevant because they mediate most of the miRNAmRNA interactions [15]. These isomiRs can regulate the same targets as the canonical miRNAs [16].

\section{MECHANISM OF ACTION}

The miRNAs binds to specific regions on the target mRNA. Depending upon the region, the effect they produce also varies. Studies have shown that the miRNAs, when binding to specific sequence at the 3'UTR of target mRNA induce translational repression, mRNA de adenylation and decapping $[17,18]$. When they bind to 5'UTR and coding region, they have silencing effect on gene expression. When the interactions are with promoter region, they can induce transcription [19, 20, 21].

The guide strand along with AGO2 protein forms a ribonucleoprotein complex termed the miRNAinduced silencing complex (miRISC). Of the four paralogs of AGO family, AGO2 most frequently takes part in construction of miRISC [22] along with the trinucleotide repeat containing protein 6 (TNRC6). These are also known as glycinetryptophan 182-kDa protein, GW182). GW182 provides the scaffolding needed to recruit other effector proteins like poly(A)-deadenylase complexes PAN2-PAN3 and CCR4-NOT following miRNA: target mRNA interaction (50) [23].

PAN2/3 helps in initiating deadenylation of mRNA which is then completed by CCR4-NOT. The bound guide strand directs the interactions of miRISC with partially complementary sequences in target mRNAs. These complementary sequences are known as miRNA response elements (MREs) and they determine the target specificity of miRISC.
They are most commonly located in the $3^{\prime}$ untranslated region.

The degree of complementarity is the key factor that determines the fate of target mRNA [24]. When the miRNA: MRE interactions are fully complementary, target mRNA cleavage occurs through AGO2 endonuclease activity [24]. Majority of miRNA: MRE interactions in animal cells are not fully complementary [23]. When there are mismatches, AGO2 endonuclease activity is prevented. AGO2 acts similar to the other non endonucleolytic AGO family members like AGO1, 3 and 4 leading to target mRNA decay.

\section{miRNA PROFILING}

miRNA plays a major role in regulation of processes including tissue differentiation, development and maintenance of an organism. Hence they can be used to identify the tissue differentiation stages of diseases like cancer. The miRNA released into extracellular fluids show high stability and resist degradation both at room temperature and under deleterious conditions. Their measurability is also greater when compared to proteins because they can be amplified as required. Thus they find application as biomarkers for diagnosis of diseases and also for forensic purposes.

Sample processing and RNA extraction are the vital steps needed for miRNA profiling. A wide range of cell and tissue sources including the body fluids serve as samples for miRNA extraction. The principles of isolation of miRNAs in a cell or tissue sample is same like that for total RNA, but may need special precautions to preserve the small RNA fraction [29]. The major approaches used currently for profiling are quantitative reverse transcriptionPCR (qRT-PCR), hybridisation-based methods and high throughput sequencing. In qRT-PCR, reverse transcription of miRNA to cDNA takes place which is then subjected to quantitative polymerase chain reaction followed by real time monitoring of the reaction products. This method can be used for absolute quantification of miRNA. A limitation is that only known miRNAs can be detected. Moreover it is labour intensive if large experiments are to be carried out. 
Hybridisation based methods include micro arrays, which is one of the first methods that can identify large number of miRNAs by parallel analysis. They have lower specificity when compared to other methods, hence the results obtained should be validated by qRT-PCR or northern blot. This is a least expensive method. The microarray hybridization assays can also only detect miRNAs that have already been described and cannot be used for absolute quantification.

RNA-sequencing is another major approach for miRNA profiling. They are helpful to detect both already described and new miRNAs and their sequence variants [30]. But data analysis require computational support and this method cannot quantify miRNA. A faster and less biased technique currently in use is the single molecule real-time sequencing (SMRT). Their high error rates and cost makes them less acceptable for wide use [31]. The applications of miRNA profiling includes novel miRNA detection, understanding various gene regulatory network processes, developmental biology etc. Those in body fluids have applications in forensic setting also.

\section{miRNAs IN PERIODONTAL DISEASE}

Lee et al. (2011), Xie et al. (2011), Perri et al. (2012), Stoecklin-Wasmer et al. (2012) were the few investigators who did pioneer studies for knowing the expression of miRNAs in healthy and diseased gingival tissues [32, 33, 34, 35]. Of these, the largest study available so far was by Stoecklin-Wasmer et al, in 2012 [34] where they evaluated 86 systemically healthy, non-smoking subjects with moderate to severe periodontitis. In their study, 40 gingival tissue samples harvested from periodontally healthy sites and 158 from diseased sites were subjected to genome-wide miRNA profiling. Microbial colonization patterns in the proximal periodontal pockets [36] were also available from these tissue biopsies. The results showed that there's about 159 miRNAs that are differentially expressed between healthy and diseased gingival tissues. Of these, 91 were over expressed and 68 were under expressed in disease versus health. This study have validated for the first time particular genes involved in tissue homeostasis and inflammatory/immune responses [34].

In all these studies, the miRNA expression assessed, was done in whole tissue gingival biopsies mixed with other cellular components. These cellular components may show variations in their proportions significantly between health and disease. Hence, it is uncertain whether the increased expression of a specific miRNA, seen in any condition, is a true increased transcription of the particular sequence, or is because of the proliferation of any cellular component that harbours the transcript, or a combination of both. This is a major limitation in most of the miRNA studies. But there is enough evidence that suggests particular miRNAs have specific role in molecular and cellular pathways involved in periodontal tissue inflammation.

\section{miRNAs IN INNATE IMMUNE RESPONSE}

The innate immune response is the host's first line defence against pathogens. This is characterised by the interaction of pattern-recognition receptors like toll-like receptors, with the pathogens. These receptors, through the intracellular signalling cascades, trigger direct cellular responses, like cytokine production [37]. In periodontal diseases, toll-like receptor-2 and toll-like receptor-4 interacts with specific pathogens and their biofilm components like lipopolysaccharide from Porphyromonas gingivalis, Aggregatibacter actinomycetemcomitans and other gram-negative periodontal species [38].

The toll-like receptor binding interactions can be down regulated by pathways that involve the NF-KB (nuclear factor kappa light chain enhancer of activated B cells) family. The NF-KB family is targeted by several miRNAs, important one being the miR-146a. When the bacterial stimuli acts via Toll-like receptors-2/4/5/9, NF-KB activation occurs which can regulate miR-146a. They trigger a negative feedback loop that down regulates the two key NF-KB/tumour necrosis factor signalling adapter molecules, namely interleukin-1 receptorassociated kinase-1 and tumour necrosis factor receptor associated factor-6 [39]. Hence, this is an immunosuppressive miRNA that regulates the 
immune responses in periodontitis. It is significantly up-regulated in inflamed gingival tissues when compared to healthy gingiva. Moreover, the Tolllike receptor-2-mediated inflammatory responses were suppressed by miR-146a in the keratinocytes [40] and macrophages [41] preventing the development of excessive inflammation [42].

Another miRNA, miR-155, also have a role in innate immunity acting via the NF-KB pathway $[43,44]$. Toll-like receptor ligation by both bacterial and viral stimuli or the stimulation by cytokines, signals NFKB pathways causing indirect induction of miR-155. $[45,46]$. In periodontal ligament cells, the induction of miR-155 down-regulates NF-KB signalling and promotion of cell differentiation [47]. They mediate type I interferon response to infection, [48] a feature often associated with aggressive periodontitis [49]. They are also capable of suppressing the expression of inositol phosphatase SHIP critical for the survival of primary gingival epithelial cells infected with P.gingivalis [50]. They induce activation of natural killer cells [51] and increases the production of interferon $-\gamma$ [52].

Two additional miRNAs that have natural killer cell regulatory roles are miR-30e and miR-200a. miR30 e inhibits natural killer cell cytotoxicity [53], whereas miR-200e negatively regulates interleukin12 signalling in natural killer cells [54]. These miRNAs have reduced expression in periodontitis and hence explains the increased activation of natural killer cells and higher interferon- $\gamma$ production associated with periodontal tissue destruction $[55,56]$. Both miR-146b and miR-155 can mediate the increase in Toll-like receptor responsiveness in macrophages, which is triggered by leukotriene B4. Leukotriene B4 levels positively correlates with severity of periodontitis [57]. Dysregulation of expression of these micro RNAs in P.gingivalis infected primary oral epithelial cells can induce Toll-like receptor signalling $[58,59]$. Studies have confirmed that the anti-inflammatory agent triclosan can modulate the expression of these miRNA, thereby normalizing the Toll like receptor signalling [60].
Lethal-7 $i$ is a member of the highly conserved lethal-7 miRNA family [61] that directly targets the Toll-like receptor-4. They are found to be overexpressed in periodontitis affected gingival tissues. miR-31 is another miRNA down regulated in periodontitis. It is a negative regulator of NF-KB [62] thus containing the excessive NF-KB-mediated inflammation. Opposing this action, miR-486 acts by disrupting the multiple NF-KB negative feedback loops, thereby sustaining NF-KB signalling [63]. Thus they are also strongly overexpressed in periodontitis lesions.

miR-141, is a major miRNA associated with gingival health. They target mitogen-activated protein kinase MAP4K4. In periodontal disease, miR-141 is down regulated, inducing MAP kinase signalling and its pro-inflammatory down-stream events [64]. Leukocyte migration is mediated by the chemokine stromal-cell derived factor-1 (SDF-1/CXCL12). This factor along with its receptor CXCR4 $[68,69]$ is strongly up regulated in periodontitis. This is also a target of miR-141.The neutrophil migration from the gingival micro-vasculature into the periodontal pocket is also mediated by chemotactic factors like interleukin-865 and granulocyte chemotactic protein-2 (GCP2/CXCL6) [66]. miR-451 [67] is a dicer independent miRNA that can suppress neutrophil chemotaxis via the p38 MAPK pathway [68] and is strongly induced in periodontitis.

The innate and adaptive immunity bridges by means of dendritic cells. These are antigen presenting cells that mediate cellular response. Thus dendritic cell signalling is a crucial step that drives the immune responses in periodontal infections and these signalling pathways are also regulated by miRNAs [70]. miR-155 plays role in dendritic cell maturation and function whereas miR-146a impair Toll- signalling in dendritic cells to reduce the amount of cytokines produced by these cells [71].

miR-45 also reduce cytokine secretion by infected dendritic cells using a negative feedback loop72. Their levels are often high in the inflamed gingiva. miR-148a was also known to impair innate response and antigen presentation of dendritic cells by interfering with intracellular calcium homeostasis [73]. miR-29a is another miRNA with elevated 
expression in diseased gingival tissues that downregulates interleukin-23. This particular micro RNA can be induced by NOD2 signalling, a pathway recently implicated in the pathogenesis of periodontal disease [74]. Thus the innate immune responses are often regulated by several miRNAs that can either inhibit or trigger inflammatory pathways, mostly via the NF-KB signalling [75].

\section{miRNAs IN ADAPTIVE IMMUNE RESPONSE}

The adaptive immune system provides immunological memory to the host. It involves both T-and B-cell mediated responses. Adaptive immunity plays role in established periodontal lesions and this accounts for the high proportions of antibody-producing plasma cells in these lesions [76]. Several miRNAs are potent regulators of adaptive immunity with suspected roles in periodontal disease. miR-146a plays a significant role in B cell development and induce a brake on autoimmunity [77]. This miRNA exerts an immune restriction that is critical for adequate $B$ cell response [78]. miR-650 is another micro RNA that influences the proliferation capacity of $B$ cells [79]. Both these are found to be up-regulated in periodontitis lesions. miR-155 plays a role in innate as well as adaptive immune response [80]. They regulate type I interferon signalling and control CD8 T-cell responses [81,82]. They activate cytokine gene expression in Th17 and T regulatory cells [83]. Through the dendritic cell signalling, they indirectly activate Th17 responses [84] and by inhibition of interferon-gamma signalling, they induce Th1 differentiation of CD4+ cells [85]. miR-210 acts contrary to miR-155 and are under-expressed in periodontitis lesions. They impair the immune suppressive functions of regulatory T-cells [86]. When down-regulated, they promote regulatory $\mathrm{T}$ cell signalling [87]. miR-155 bring about biological effects by direct action on target genes. Moreover, there is a hierarchy of miRNAs that are directly or indirectly regulated by miR-155, bringing about certain biological effects. For example, miR-155 deficiency results in lower levels of miR-455 in murine dendritic cells [88]. Thus miRNA signalling has a crucial role in the regulation of adaptive immunity in periodontal disease.

\section{microRNAs IN BONE REMODELLING}

The miRNAs implicated in healthy or periodontitisaffected gingival tissues have specific role in bone homeostasis also. miR-148a, induced by receptor activator of NF-KB ligand (RANKL), [89] is a micro RNA mediating osteoclastogenesis in CD14+ peripheral blood mononuclear cells. On the contrary, miR-29a modulates signalling in human osteoblasts leading to osteoblast differentiation [90]. miR-31 is found to be down regulated in periodontitis affected gingival tissues. They mediate osteoclastogenesis and repress osteogenesis leading to impaired osteoclast formation and reduced bone resorption [91, 92, 93, 94] Similarly, miR-200c is also down regulated in periodontitis. They are known to induce odontogenesis and osteoclastogenesis [27], thereby regulating the excessive bone loss in periodontal inflammation.

\section{CONCLUSIONS}

Since the discovery of miRNAs in the earlier 1990s, numerous studies have been made on their production, effects on gene expression and involvement in various physiological and pathological events. Most of these studies were conducted in vitro but to know the endogenous miRNA functions, in vivo studies are also required. miRNAs can modulate the expression of target mRNAs in different pathways. They may also regulate other non-coding RNAs at post transcriptional levels so the miRNA regulatory cascades are not limited to protein coding transcripts. It is now a known fact that circulating miRNAs can serve as biomarkers for diseases. They also play important roles in intercellular communication. Some miRNAs can even interact with cell surface receptors, such as Toll like receptors thus having hormone like activities too. miRNAs have key role in regulating gene expression in mammalian cells affecting several molecular and cellular pathways. Their specific role in maintaining homeostasis of periodontal tissues is well documented. Future studies are needed to expand these early findings, thus aiming to understand the differential expression of several miRNAs between 'healthy' and 'diseased' gingival tissues. This can ultimately enhance our understanding of the pathobiology of periodontal diseases. 


\section{ACKNOWLEDGEMENT}

The authors would like to acknowledge the authors and publishers of all those articles and journals that has been cited in this manuscript.

\section{DECLARATION OF INTEREST}

The author reports no conflicts of interest. The author alone is responsible with the content of this article.

\section{REFERENCES}

1. Crick FH. The biological replication of macromolecules. Symp. Soc. Exp. Biol. 1958;138-163.

2. Friedman RC, Farh KK, Burge CB, Bartel DP. Most mammalian mRNAs are conserved targets of microRNAs. Genome Res. 2009;19:92-105.

3. Lee RC, Feinbaum RL, Ambros V. The C. elegans heterochronic gene LIN-4 encodes small RNAs with antisense complementarity to LIN-14. Cell. 1993;75:843-854.

4. Wightman B, Ha I, Ruvkun G. Posttranscriptional regulation of the heterochronic gene LIN-14 by LIN-4 mediates temporal pattern formation in C. elegans. Cell. 1993;75:855-862.

5. Griffiths-Jones S. The microRNA registry. Nucleic Acids Res. 2004;32:D109-D111.

6. Ha M, Kim VN. Regulation of microRNA biogenesis. Nat Rev Mol Cell Biol. 2014;15:509-524.

7. Marco A, Ninova M, Griffiths-Jones S. Multiple products from microRNA transcripts. Biochem Soc Trans. 2013;41:850-854.

8. Borchert GM, Lanier W, Davidson BL. RNA polymerase III transcribes human microRNAs. Nat Struct Mol Biol. 2006;13:1097-1101.

9. Roth BM, Ishimaru D, Hennig M. The core microprocessor component diGeorge syndrome critical region 8 (DGCR8) is a nonspecific RNA-binding protein. J Biol Chem. 2013;288:26785-26799.

10. Lee Y, Ahn C, Han J, Choi H, Kim J, Yim J, Lee J, Provost P, Radmark O, Kim S, Kim VN. The nuclear RNAse III Drosha initiates microRNA processing. Nature. 2003;425:415-419.

11. Yi R, Qin Y, Macara IG, Cullen BR. Exportin-5 mediates the nuclear export of pre-microRNAs and short hairpin RNAs. Genes Dev. 2003;17:3011-3016.

12. Guo L, Zhao $\mathrm{Y}$, Yang S, Zhang H, Chen F. A genome-wide screen for non-template nucleotides and isomir repertoires in miRNAs indicates dynamic and versatile microRNAome. Mol Biol Rep. 2014;41:6649-6658.

13. Guo L, Chen F. A challenge for miRNA: Multiple isomirs in miRNAomics. Gene. 2014;544:1-7.

14. Neilsen CT, Goodall GJ, Bracken CP. IsomiRs--the overlooked repertoire in the dynamic microRNAome. Trends Genet. 2012;28:544-549.

15. Tan GC, Chan E, Molnar A, Sarkar R, Alexieva D, Isa IM, Robinson S, Zhang S, Ellis P, Langford CF, Guillot PV, Chandrashekran A, Fisk NM, Castellano L, Meister G, Winston RM, Cui W, Baulcombe D, Dibb NJ. 5' isomir variation is of functional and evolutionary importance. Nucleic Acids Res. 2014;42:9424-9435.

16. Martin HC, Wani S, Steptoe AL, Krishnan K, Nones K, Nourbakhsh E, Vlassov A, Grimmond SM, Cloonan N. Imperfect centered miRNA binding sites are common and can mediate repression of target mRNAs. Genome Biol. 2014;15:R51.

17. Huntzinger $E$, Izaurralde $E$. Gene silencing by microRNAs: contributions of translational repression and mRNA decay. Nat Rev Genet. 2011;12:99-110.

18. Ipsaro JJ, Joshua-Tor L. From guide to target: molecular insights into eukaryotic RNA-interference machinery. Nat Struct Mol Biol. 2015;22:20-28.

19. Forman JJ, Legesse-Miller A, Coller HA. A search for conserved sequences in coding regions reveals that the let-7 microRNA targets Dicer within its coding sequence. Proc Natl Acad Sci USA. 2008;105:14879-84. 
20. Zhang J, ZhouW, Liu Y, Liu T, Li C, Wang L. Oncogenic role of microRNA-532-5p in human colorectal cancer via targeting of the $5^{\prime}$ UTR of RUNX3. Oncol Lett. 2018;15:7215-7220.

21. Dharap A, Pokrzywa C, Murali S, Pandi G, Vemuganti R. MicroRNA miR-324-3p induces promotermediated expression of RelA gene. PLoS ONE 2013;8:e79467.

22. Meister G. Argonaute proteins: Functional insights and emerging roles. Nat Rev Genet. 2013;14:447-459.

23. Jonas $\mathrm{S}$, Izaurralde $\mathrm{E}$. Towards a molecular understanding of microRNA-mediated gene silencing. Nat Rev Genet. 2015;16:421-33.

24. Jo MH, Shin S, Jung SR, Kim E, Song JJ, Hohng S. Human Argonaute 2 Has diverse reaction pathways on Target RNAs. Mol Cell. 2015;59:117-24.

25. Murata K, Yoshitomi H, Furu M, Ishikawa M, Shibuya H, Ito H, Matsuda Micro RNA-451 downregulates neutrophil chemotaxis via p38 MAPK. Arthritis Rheumatol. 2014;66:549-559.

26. Nahid MA, Rivera M, Lucas A, Chan EK, Kesavalu L. Polymicrobial infection with periodontal pathogens specifically enhances microRNA miR-146a in APOE-/- mice during experimental periodontal disease. Infect Immun. 2011;79:1597-1605.

27. Nakao A, Kajiya H, Fukushima H, Fukushima A, Anan H, Ozeki S, Okabe K. PTHRP induces notch signaling in periodontal ligament cells. J Dent Res. 2009;88:551-556.

28. Nallamshetty S, Chan SY, Loscalzo J. Hypoxia: A master regulator of microRNA biogenesis and activity. Free Radic Biol Med. 2013;64:20-30.

29. Accerbi $M$, et al. Methods for isolation of total RNA to recover miRNAs and other small RNAs from diverse species. Methods Mol Biol. 2010;592:31-50.

30. Tam S, de Borja R, Tsao MS, McPherson JD. Robust global microRNA expression profiling using next-generation sequencing technologies. Lab Invest. 2014;94:350- 358.

31. Kapranov $P$, et al. New class of gene-termini-associated human RNAs suggests a novel RNA copying mechanism. Nature. 2010;466:642-6.

32. Lee YH, Na HS, Jeong SY, Jeong SH, Park HR, Chung J. Comparison of inflammatory microRNA expression in healthy and periodontitis tissues. Biocell. 2011;35:43-49.

33. Perri R, Nares S, Zhang S, Barros SP, Offenbacher S. MicroRNA modulation in obesity and periodontitis. J Dent Res. 2012;91:33-38.

34. Stoecklin-Wasmer C, Guarnieri P, Celenti R, Demmer RT, Kebschull M, Papapanou PN. MicroRNAs and their target genes in gingival tissues. J Dent Res. 2012;91:934- 940.

35. Xie YF, Shu R, Jiang SY, Liu DL, Zhang XL. Comparison of microRNA profiles of human periodontal diseased and healthy gingival tissues. Int J Oral Sci. 2011;3:125- 134.

36. Papapanou PN, Behle JH, Kebschull M, Celenti R, Wolf DL, Handfield M, Pavlidis P, Demmer RT. Subgingival bacterial colonization profiles correlate with gingival tissue gene expression. BMC Microbiol. 2009;9:221.

37. Garlet GP. Destructive and protective roles of cytokines in periodontitis: A re-appraisal from host defense and tissue destruction viewpoints. J Dent Res. 2010;89:1349-1363.

38. Benakanakere M, Kinane DF. Innate cellular responses to the periodontal biofilm. Front Oral Biol. 2012;15:41-55.

39. Taganov KD, Boldin MP, Chang KJ, Baltimore D. Nf-kappa B-dependent induction of microRNA mir146 , an inhibitor targeted to signaling proteins of innate immune responses. Proc Natl Acad Sci USA. 2006;103:12481-12486.

40. Meisgen F, Xu Landen N, Wang A, Rethi B, Bouez C, Zuccolo M, Gueniche A, Stahle M, Sonkoly E, Breton L, Pivarcsi A. miR-146a negatively regulates TLR2-induced inflammatory responses in keratinocytes. J Invest Dermatol. 2014;134:1931-1940.

41. Quinn EM, Wang JH, O'Callaghan G, Redmond HP. MicroRNA-146a is upregulated by and negatively regulates TLR2 signaling. PLoS One. 2013;8:e62232.

42. Staedel C, Darfeuille F. MicroRNAs and bacterial infection. Cell Microbiol. 2013; 15:1496-1507.

43. Elton TS, Selemon H, Elton SM, Parinandi NL. Regulation of the miR155 host gene in physiological and pathological processes. Gene. 2013;532:1-12. 
44. Thompson RC, Vardinogiannis I, Gilmore TD. Identification of an NF-kappaB p50/p65-responsive site in the human miR155hg promoter. BMC Mol Biol. 2013;14:24.

45. Cremer TJ, Fatehchand K, Shah P, Gillette D, Patel H, Marsh RL, Besecker BY, Rajaram MV, CormetBoyaka E, Kanneganti TD, Schlesinger LS, Butchar JP, Tridandapani S. miR-155 induction by microbes/microbial ligands requires NF-kappaB-dependent de novo protein synthesis. Front Cell Infect Microbiol. 2012;2:73.

46. Cremer TJ, Ravneberg DH, Clay CD, Piper-Hunter MG, Marsh CB, Elton TS, Gunn JS, Amer A, Kanneganti TD, Schlesinger LS, Butchar JP, Tridandapani S. miR-155 induction by F. novicida but not the virulent $F$. tularensis results in ship down-regulation and enhanced pro-inflammatory cytokine response. PLoS One. 2009;4:e8508.

47. Hung PS, Chen FC, Kuang SH, Kao SY, Lin SC, Chang KW. miR-146a induces differentiation of periodontal ligament cells. J Dent Res. 2010;89:252-257.

48. Wang P, Hou J, Lin L, Wang C, Liu X, Li D, Ma F, Wang Z, Cao X. Inducible microRNA-155 feedback promotes type I IFN signaling in antiviral innate immunity by targeting suppressor of cytokine signaling 1. J Immunol. 2010;185:6226-6233.

49. Nowak M, Kramer B, Haupt M, Papapanou PN, Kebschull J, Hoffmann P, Schmidt-Wolf IG, Jepsen $\mathrm{S}$, Brossart P, Perner S, Kebschull M. Activation of invariant NK T cells in periodontitis lesions. J Immunol. 2013;190:2282-2291.

50. Yilmaz O, Jungas T, Verbeke P, Ojcius DM. Activation of the phosphatidylinositol 3-kinase/akt pathway contributes to survival of primary epithelial cells infected with the periodontal pathogen Porphyromonas gingivalis . Infect Immun. 2004;72:3743-3751.

51. Trotta R, Chen L, Costinean S, Josyula S, Mundy-Bosse BL, Ciarlariello D, Mao C, Briercheck EL, McConnell KK, Mishra A, Yu L, Croce CM, Caligiuri MA. Overexpression of miR-155 causes expansion, arrest in terminal differentiation and functional activation of mouse natural killer cells. Blood. 2013;121:3126-3134.

52. Trotta R, Chen L, Ciarlariello D, Josyula S, Mao C, Costinean S, Yu L, Butchar JP, Tridandapani S, Croce CM, Caligiuri MA. miR-155 regulates IFN-gamma production in natural killer cells. Blood. 2012;119:3478-3485.

53. Wang $P$, Gu Y, Zhang $Q$, Han Y, Hou J, Lin L, Wu C, Bao Y, Su X, Jiang M, Wang Q, Li N, Cao X. Identification of resting and type I IFN-activated human NK cell mirnomes reveals microRNA-378 and microRNA-30e as negative regulators of NK cell cytotoxicity. J Immunol. 2012;189:211-221.

54. Huang $Y$, Lei $Y$, Zhang $H$, Hou L, Zhang M, Dayton Al. MicroRNA regulation of stat4 protein expression: Rapid and sensitive modulation of IL-12 signalling in human natural killer cells. Blood. 2011;118:6793-6802.

55. Chaushu S, Wilensky A, Gur C, Shapira L, Elboim M, Halftek G, Polak D, Achdout H, Bachrach G, Mandelboim $O$. Direct recognition of Fusobacterium nucleatum by the NK cell natural cytotoxicity receptor nkp46 aggravates periodontal disease. PLoS Pathog. 2012;8:e1002601.

56. Kramer B, Kebschull M, Nowak M, Demmer RT, Haupt M, Korner C, Perner S, Jepsen S, Nattermann J, Papapanou PN. Role of the NK cell-activating receptor CRACC in periodontitis. Infect Immun. 2013;81:690-696.

57. Pradeep AR, Manjunath SG, Swati PP, Shikha C, Sujatha PB. Gingival crevicular fluid levels of leukotriene $B 4$ in periodontal health and disease. J Periodontol. 2007;78:2325-2330.

58. Hou J, Wang P, Lin L, Liu X, Ma F, An H, Wang Z, Cao X. MicroRNA-146a feedback inhibits RIG-idependent type i IFN production in macrophages by targeting TRAF6, IRAK1, and IRAK2. J Immunol. 2009;183:2150-2158.

59. Ruggiero T, Trabucchi M, De Santa F, Zupo S, Harfe BD, McManus MT, Rosenfeld MG, Briata P, Gherzi R. LPS induces kh-type splicing regulatory protein-dependent processing of microRNA-155 precursors in macrophages. FASEB J. 2009;23:2898- 2908.

60. Neiva KG, Calderon NL, Alonso TR, Panagakos F, Wallet SM. Type 1 diabetes-associated TLR responsiveness of oral epithelial cells. J Dent Res. 2014;93:169-174.

61. Roush S, Slack FJ. The LET-7 family of microRNAs. Trends Cell Biol. 2008;18:505-516. 
62. Xu N, Meisgen F, Butler LM, Han G, Wang XJ, Soderberg-Naucler C, Stahle M, Pivarcsi A, Sonkoly E. MicroRNA-31 is overexpressed in psoriasis and modulates

63. inflammatory cytokine and chemokine production in keratinocytes via targeting serine/threonine kinase 40. J Immunol. 2013;190:678-688.

64. Song L, Lin C, Gong H, Wang C, Liu L, Wu J, Tao S, Hu B, Cheng SY, Li M, Li J. miR-486 sustains NFkappaB activity by disrupting multiple NF-kappaB-negative feedback loops. Cell Res. 201323:274289.

65. Zhao G, Wang B, Liu Y, Zhang JG, Deng SC, Qin Q, Tian K, Li X, Zhu S, Niu Y, Gong Q, Wang CY. MiRNA-141, downregulated in pancreatic cancer, inhibits cell proliferation and invasion by directly targeting MAP4K4. Mol Cancer Ther. 2013;12:2569-2580.

66. Tonetti MS, Imboden MA, Lang NP. Neutrophil migration into the gingival sulcus is associated with transepithelial gradients of interleukin-8 and ICAM-1. J Periodontol. 1998;69:1139-1147.

67. Kebschull M, Demmer R, Behle JH, Pollreisz A, Heidemann J, Belusko PB, Celenti R, Pavlidis P, Papapanou PN. Granulocyte chemotactic protein 2 (GCP-2/CXCL6) complements interleukin-8 in periodontal disease. J Periodontal Res. 2009;44:465- 471.

68. Yang JS, Maurin T, Robine N, Rasmussen KD, Jeffrey KL, Chandwani R, Papapetrou EP, Sadelain M, O'Carroll D, Lai EC. Conserved vertebrate miR-451 provides a platform for Dicer-independent, AGO2-mediated microRNA biogenesis. Proc Natl Acad Sci USA. 2010;107:15163-15168.

69. Havens AM, Chiu E, Taba M, Wang J, Shiozawa Y, Jung Y, Taichman LS, D'Silva NJ, Gopalakrishnan R, Wang C, Giannobile WV, Taichman RS. Stromal-derived factor-1alpha (CXCL12) levels increase in periodontal disease. J Periodontol. 2008;79:845-853.

70. Kebschull M, Guarnieri P, Demmer RT, Boulesteix AL, Pavlidis P, Papapanou PN. Molecular differences between chronic and aggressive periodontitis. J Dent Res. 2013;92:1081-1088.

71. Smyth LA, Boardman D, Tung S, Lechler R, Lombardi G. MicroRNAs affect dendritic cells function and phenotype. Immunology. 2015;144:197-205.

72. Karrich JJ, Jachimowski LC, Libouban M, Iyer A, Brandwijk K, Taanman-Kueter EW, Nagasawa M, de Jong EC, Uittenbogaart $\mathrm{CH}$, Blom B. MicroRNA-146a regulates survival and maturation of human plasmacytoid dendritic cells. Blood. 2013;122:3001- 3009.

73. Rosenberger CM, Podyminogin RL, Navarro G, Zhao GW, Askovich PS, Weiss MJ, Aderem A. miR451 regulates dendritic cell cytokine responses to influenza infection. J Immunol. 2012;189:59655975.

74. Liu X, Zhan Z, Xu L, Ma F, Li D, Guo Z, Li N, Cao X. MicroRNA-148/152 impair innate response and antigen presentation of TLR-triggered dendritic cells by targeting camkiialpha. J Immunol. 2010;185:7244-7251.

75. Yuan H, Zelka S, Burkatovskaya M, Gupte R, Leeman SE, Amar S. Pivotal role of NOD2 in inflammatory processes affecting atherosclerosis and periodontal bone loss. Proc Natl Acad Sci USA. 2013;110:E5059-E5068.

76. Rebane A, Akdis CA. MicroRNAs: Essential players in the regulation of inflammation. J Allergy Clin Immunol. 2013;132:15-26.

77. Smith M, Seymour GJ, Cullinan MP. Histopathological features of chronic and aggressive periodontitis. Periodontol 2000. 2010;53:45-54.

78. Boldin MP, Taganov KD, Rao DS, Yang L, Zhao JL, Kalwani M, Garcia-Flores Y, Luong M, Devrekanli A, Xu J, Sun G, Tay J, Linsley PS, Baltimore D. miR-146a is a significant brake on autoimmunity, myeloproliferation, and cancer in mice. J Exp Med. 2011;208:1189-1201.

79. Lindner JM, Kayo H, Hedlund S, Fukuda Y, Fukao T, Nielsen PJ. Cutting edge: The transcription factor BOB1 counteracts B cell activation and regulates miR-146a in B cells. J Immunol. 2014;192:4483-4486.

80. Mraz M, Dolezalova D, Plevova K, Stano Kozubik K, Mayerova V, Cerna K, Musilova K, Tichy B, Pavlova S, Borsky M, Verner J, Doubek M, Brychtova Y, Trbusek M, Hampl A, Mayer J, Pospisilova S. MicroRNA-650 expression is influenced by immunoglobulin gene rearrangement and affects the biology of chronic lymphocytic leukemia. Blood. 2012;119:2110-2113. 
81. Seddiki N, Brezar V, Ruffin N, Levy Y, Swaminathan S. Role of miR-155 in the regulation of lymphocyte immune function and disease. Immunology. 2014;142:32- 38.

82. Lind EF, Ohashi PS. miR-155, a central modulator of T-cell responses. Eur J Immunol. 2014;44:1115.

83. Gracias DT, Stelekati E, Hope JL, Boesteanu AC, Doering TA, Norton J, Mueller YM, Fraietta JA, Wherry EJ, Turner M, Katsikis PD. The microRNA miR-155 controls CD8(+) T cell responses by regulating interferon signaling. Nat Immunol. 2013;14:593-602.

84. Escobar TM, Kanellopoulou C, Kugler DG, Kilaru G, Nguyen CK, Nagarajan V, Bhairavabhotla RK, Northrup D, Zahr R, Burr P, Liu X, Zhao K, Sher A, Jankovic D, Zhu J, Muljo SA. miR-155 activates cytokine gene expression in TH17 cells by regulating the DNA-binding protein JARID2 to relieve polycomb-mediated repression. Immunity. 2014;40:865-879.

85. O'Connell RM, Kahn D, Gibson WS, Round JL, Scholz RL, Chaudhuri AA, Kahn ME, Rao DS, Baltimore D. MicroRNA-155 promotes autoimmune inflammation by enhancing inflammatory $T$ cell development. Immunity. 2010;33:607-619.

86. Banerjee A, Schambach F, DeJong CS, Hammond SM, Reiner SL. Micro-RNA-155 inhibits IFNgamma signaling in CD4+ T cells. Eur J Immunol. 2010;40:225-231.

87. Zhao M, Wang LT, Liang GP, Zhang P, Deng XJ, Tang Q, Zhai HY, Chang CC, Su YW, Lu QJ. Upregulation of microRNA-210 induces immune dysfunction via targeting FOXP3 in CD4 (+) T cells of psoriasis vulgaris. Clin Immunol. 2014;150:22-30.

88. Parachuru VP, Coates DE, Milne TJ, Hussaini HM, Rich AM, Seymour GJ. Forkhead box P3-positive regulatory T-cells and interleukin 17-positive T-helper 17 cells in chronic inflammatory periodontal disease. J Periodontal Res. 2014;49:817-826.

89. Dueck A, Eichner A, Sixt M, Meister G. A miR-155-dependent microRNA hierarchy in dendritic cell maturation and macrophage activation. FEBS Lett. 2014;588:632-640.

90. Cheng P, Chen C, He HB, Hu R, Zhou HD, Xie H, Zhu W, Dai RC, Wu XP, Liao EY, Luo XH. miR-148a regulates osteoclastogenesis by targeting $\mathrm{v}$-maf musculoaponeurotic fibrosarcoma oncogene homolog b. J Bone Miner Res. 2013;28:1180-1190.

91. Kapinas K, Kessler C, Ricks T, Gronowicz G, Delany AM. miR-29 modulates wnt signaling in human osteoblasts through a positive feedback loop. J Biol Chem. 2010;285:25221-25231.

92. Baglio SR, Devescovi V, Granchi D, Baldini N. MicroRNA expression profiling of human bone marrow mesenchymal stem cells during osteogenic differentiation reveals osterix regulation by mir-31. Gene. 2013;527:321-331.

93. Deng $Y$, Wu S, Zhou H, Bi X, Wang $Y$, Hu Y, Gu P, Fan X. Effects of a miR-31, RUNX2, and SATB2 regulatory loop on the osteogenic differentiation of bone mesenchymal stem cells. Stem Cells Dev. 2013;22:2278-2286.

94. Mizoguchi F, Murakami Y, Saito T, Miyasaka N, Kohsaka H. miR-31 controls osteoclast formation and bone resorption by targeting rhoa. Arthritis Res Ther. 2013;15:R102.

95. Xie $Q$, Wang Z, Bi X, Zhou H, Wang Y, Gu P, Fan X. Effects of miR-31 on the osteogenesis of human mesenchymal stem cells. Biochem Biophys Res Commun. 2014;446:98-104.

\section{Editorial History}

Date of Submission: 11 January 2020

Review and Revision: 15 January 2020 to 13 March 2020

Accepted: 02 March 2020

Published: 21 April 2020

License Information: This work is licensed under a Creative Commons Attribution 